\title{
Calix|6|arene Bearing Carboxylic Acid and Amide Groups in Polymeric CTA Membrane
}

\author{
Jong Seung Kim, ${ }^{\star}$ Soo Heon Lee, Sang Hyeok Yu, ${ }^{\dagger}$ Moon Hwan Cho, ${ }^{\dagger}$ \\ Dong Won Kim, Seon-Gil Kwon, and Eil-Hee Lee \\ Department of (hemisty. Konvang lniversity, Nonsan 320-711, Korea \\ -Department of Chemistry, Kangwon National Thiversin, (huncheon 200-711, Norea

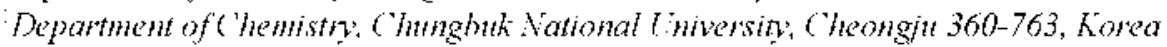 \\ 'Korea Atomic Energy' Research Institute, Daejeon 305-600, Korea \\ Received I/oy 16, 2002
}

\begin{abstract}
Caliv[6]arene having both carboxylic acid (1,3,5-) and carboxamide $(2,4,6-)$ in an altemative way was swnthesized. Transport rates of alkali and alkaline-eath netal ions were tested in bulk licuid mentorane and polymer inclusion membrane. Ba ${ }^{2-}$ ion was lound to give the highest transpott rate among lested metal ions in both BI.M and PIM systems. In PIM syistem. high durability (longer than 30 days) of the membrame was observed.
\end{abstract}

Key words : Calix[6]arene, Membrane, Transpot experiment, Polyner inclusion membrane

\section{Introduction}

Calixarencs. which are macrocyclic compounds available in a variety of ring sizes. are of particular interest as inclusion hosts for ions and specific molccules. ${ }^{1-3}$ While crown ellers and aracrown ether atlached calix[+]arenes have long been interesting to chemists for synthesis as well as for their metal ion recognition. ${ }^{-1}$ calix[6]arenc was not that attractive not only because symthesis of the calix[6]arene derivatives is difficult but also because the conformations of the product is 100 complicated to be assigned. Recently. these calix[6]arenes having both carboxamide and carboxylic acid tails by altemative pattem have been intensiycly stuided in selective separation of the lanthanides and actinides which can cxist in atomic nuclear wastes. ${ }^{5} \mathrm{Am}^{3+}$ selcclivily (separation factor) over lanthanides in two-plase cxiraction experiment was found 10 be 108 at $\mathrm{pH} 3.0^{5}$ However. transport through polymer inclusion membrane (PIM) and bulk liquid membranc (BLM) of the metal ions using the calix[6] arene derivatives lave not becn reported yet.

Simple two phase cxiraction. bulk liquid membrane (BLM). and supporicd liquid membranc (SLM) using calixcrown derivatives has becn cxplored to investigate binding capabilitics. 1ransport rates. and transport penmeability for the cesium ion." As one of the membrane technologies. polymeric inclusion membranc (PIM) system las been recently investigated taking advantages of (i) casy sctup. (ii) ligh sclectivily. and (iii) high durability. has been dercloped. ${ }^{-8}$ PIMs will cellulose 1riacclate (CTA) polyner as a supporter. logelher wilh a lydrophobic non-yolatile organic solyent (e.g. NPOE) as a plasticizer and an organic carric were found to cover the several problems occurted in SLM system such as loss of organic carrice with plasticiere into

\footnotetext{
*To whom coresponderice should be addressed. Phone: +82-2875-4887: Fax: +82-2-874-3704: F-mail: samgroubiasnu.ac.kr
}

aqucous solution. slow transport ratc. and low durability. ${ }^{6-8} \mathrm{Wc}$ now report the experimental results of the transport flux values for the metal ions using calix[6]arene derivative + in PIMs system (single and competitive ion cxperiments) along wilh permeability coefficient $(I)$.

\section{Experimental Section}

Unless specificd othenvisc. reagent-grade reaclants and solvents were obtained from chemical suppliers and used as received. Deionized water was prepared by passing distilled water through an Organo G-10 cartridge. Calis[6]arenc derivative 1 was prepared by the adaptation of the reported procedures."

Syntheses.

1,3,5-7rimethy-2,4,6-tricarboxamide-p-tert-butlcalix $[6]$ arene (2): A mixture of $1.0 \mathrm{~g}(0.98$ mmole) of 1.3 .5 trimethyl-p-tert-buty]calix[6]arcnc. $0.497 \mathrm{~mL}$ (3.92 mmolc) of 1,1 -dicthyl-2-chloroacclamide. and $0.542 \mathrm{~g}(3.92$ mmole) of $\mathrm{K}_{2} \mathrm{CO}_{3}$ in $150 \mathrm{~mL}$ of acclonitrile refluxed for 20 lirs. The crude mixture was dissolved in $\mathrm{CH}_{2} \mathrm{Cl}_{2}$ and the treated with $10 \% \mathrm{HCl}$ solution. The organic layer was dried over $\mathrm{MgSO}_{\dashv}$. Recrystallization of the product from $\mathrm{CH}_{2} \mathrm{Cl}_{2}$ $\mathrm{McOH}(9: 1)$ gave a white crystal in $80 \%$ yicld. IR $(\mathrm{KBr}$ pelle1. $\mathrm{cm}^{3}$ ): 3452.2985 .5 .2370 .8 . 1637.2. 1482.7. 1019.4. ${ }^{\mathrm{l}} \mathrm{H}$ NMR $\left(300 \mathrm{MH} \% . \mathrm{CDCl}_{3}\right.$ ): $\delta 7.2-7.3$ (d. 6H. Ar/I). 6.596.68 (s. 6H. ArH). +6 (s. 6H. OCH.C). 3.56-4.55 (m. 12H. ArC $H_{7}$ Ar). 2.2 (s. 9H. $-\left(H_{3}\right) .1 .15-1.33$ (q. 9H. $\mathrm{NCH}_{2}\left(\mathrm{CH}_{3}\right.$ ). 1.38 (s. 27H. $t$-Bu). 0.77 (s. 27H. $t$-Bu). FAB-MS $m z\left(\mathrm{M}^{-}\right)$ calcd. 1454,92 . found 1454.90 .

1,3,5-Tricarboxamide-p-tert-butvlcalir/6/arene (3): Under nitrogen atmospleme. a mixture of $1.0 \mathrm{~g}(0.7+\mathrm{mmolc})$ of 1.3.5-1nimetlyy 1-2.4.6-1nicarboxamide-p-tert-buty lcalix[6]arene. $0.70 \mathrm{~mL}(4.9+\mathrm{mmole})$ of iodotrimethylsilane. $0.36 \mathrm{~g}(2.95$ mmole) of sodium perchlorate in $150 \mathrm{~mL}$ of chloroform refluxed for + lirs. Afier the chloroform was menoved in 
vacuo, the crude mixture was dissolved in $\mathrm{CH}_{2} \mathrm{Cl}_{2}$ and the treated with $10 \% \mathrm{HCl}$ solution. The organic layer was dried over $\mathrm{MgSO}_{1}$. Recrystallization of the product from EtOAc : hexane (l:4) gave a white crystal in $66 \%$ yield. $\mathbb{R}(\mathrm{KBr}$ pellet. $\left.\mathrm{cm}^{-1}\right): 3414.3,2965.5,2347.7,1652.6 .1482 .7 .1204 .7$; ${ }^{1} \mathrm{H}$ NMR $\left(\mathrm{CDCl}_{3}\right): \delta 7.26-6.84$ (t. 12H. ArH). $4.59-4.47$ (m. $6 \mathrm{H},-\left(\mathrm{H}_{2} \mathrm{C}\right), 4.28-3.4+$ (m. $12 \mathrm{H}$. ArC $\left.\mathrm{H}_{2} \mathrm{Ar}\right) .3 .38-3.28$ (m.

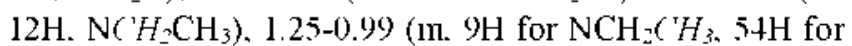
$t$-Bu). FAB-MS $m z$ (M ) calcd. 1312.84 . found 1312.80 .

1,3,5-Tricarboxylic acid-2,4,6-tricarboxamide-p-tert-butycalix/6/arene (f): Under nitrogen atmosphere. to a solution of $1.0 \mathrm{~g}(0.76 \mathrm{mmole})$ of 1.3 .5 -triamide-p-tert-butylcalix[6]arene in THF, $0.547 \mathrm{~g}$ (22.8 mumole) of sodium hydride was added slowly at $0{ }^{\circ} \mathrm{C} .0 .63 \mathrm{~g}(4.56 \mathrm{mmole})$ of bromoacetic acid in $10 \mathrm{~mL}$ of THF was added dropwise at 0 ${ }^{\text {"C }}$. Upon the complete addition. the reaction mixture was refluxed for 10 hrs. After the THF was removed in vacuo. the crude misture was dissolved in $\mathrm{CH}_{2} \mathrm{Cl}_{2}$ and the treated with $10 \% \mathrm{HCl}$ solution. The organic layer was dried over

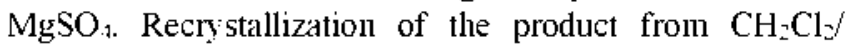
$\mathrm{MeOH}(9: 1)$ gave a colorless crystal in $82 \%$ yield. IR $(\mathrm{KBr}$ pellet, $\left.\mathrm{cm}^{-1}\right): 2965.5 .1753 .16+4.9,1482.7,1197,1119.8$, 1058: ${ }^{1} \mathrm{H}$ NMR $\left(\mathrm{CDCl}_{3}\right): \delta 7.12-7.0$ (s, 6H. ArH). 6.9-6.8 (s. $6 \mathrm{H}, \mathrm{Ar} H) .5 .3(\mathrm{~s}, 3 \mathrm{H}-\mathrm{OH}), 4.5$ (s, 12H, OCH.C). $3.8(\mathrm{~m}$. $6 \mathrm{H}$. Ar( $H_{2} \mathrm{Ar}$ ) 3.4 (m. $6 \mathrm{H}$, for $\operatorname{Ar}\left(H_{-} \mathrm{Ar}, 12 \mathrm{H}\right.$ for $\mathrm{N}^{\prime} H_{2} \mathrm{CH}_{3}$ ). 1.21-1.16 (m. $18 \mathrm{H}$ for $\mathrm{NCH}_{2}\left(\mathrm{CH}_{3} .27 \mathrm{H}\right.$ for $t$-Bu). 1.05 (s. 27H, $t$-Bu). FAB MS $m z$ (M ): calcd 1486.95. found 1486.60 .

Bulk Liquid Membrane. Membrane transport experiments were carried out using a bulk liquid membrame cell based on the concept of the Schulman bridge at $25^{\circ} \mathrm{C} .{ }^{4}$ The bottom half of the cell was filled with $3.0 \mathrm{~mL}$ of $1.0 \mathrm{mM}$ solution of the organic ligand + in clloroform and a glass tube is inserted. The interior of the tube above the organic media is filled with a $0.8 \mathrm{~mL}$ of $0.1 \mathrm{M}$ metal ion solution as a source phase. The outer cylinder is filled with $5.0 \mathrm{~mL}$ of deionized water as a receiving phase. The details of the transport conditions are summarized in the footnotes of Table 1 . The receiving phase was sampled after 24 hours stirring with 120 rpm at $25^{\circ} \mathrm{C}$ and analyzed for cation concentration using an atomic absorption spectrometer.

CTA Membrane and transport experiment. Cellulose triacetate. CTA $(0.062 \mathrm{~g})$ in $5.0 \mathrm{~mL}$ of $\mathrm{CH}_{2} \mathrm{Cl}_{2}$ was mixed with $3.0 \mathrm{~mL}$ of $10 \%(\mathrm{v} / \mathrm{N}) \mathrm{NPOE}$ (2-nitrophenyloctyl ether) in

Table 1. Single ion transport values for alkali metal ions and alkaline-earth metal ions through a bulk liquid membrane using $f^{\sigma}$

\begin{tabular}{cccccccccc}
\hline \multirow{2}{*}{ Melal } & \multicolumn{8}{c}{ Transport ratc $\left(10^{8} \mathrm{~mol} \cdot \mathrm{s}^{1} \cdot \mathrm{m}^{2}\right)^{b}$} \\
\cline { 2 - 10 } & $\mathrm{Li}$ & $\mathrm{Na}$ & $\mathrm{K}$ & $\mathrm{Rb}^{\prime}$ & $\mathrm{Cs}^{\prime}$ & $\mathrm{Mg}^{2-}$ & $\mathrm{Ca}^{21}$ & $\mathrm{Sr}^{2-}$ & $\mathrm{Ba}^{2-}$ \\
\hline 5.94 & 7.18 & 14.28 & 2.05 & 1.24 & 2.2 .3 & 8.9 .3 & 14.75 & 21.3 .3
\end{tabular}

"Transport condition: sounce phase (aqueous solution of metal nitrate, 0.8 mL. $0.1 \mathrm{M})$. membrane phase $\left(\mathrm{ClCH}_{-} \mathrm{CH}_{-} \mathrm{Cl} .3 .0 \mathrm{~mL}\right.$ ). (carrier) -1.0 $\mathrm{mM}$ : i.d. of glass vial $-18 \mathrm{~mm}$. stirred by $13 \mathrm{~mm}$ leflon-coated magnetic stiming bar driven by a Itume Symiloronous motor, receiving plase (deionized water, $5.0 \mathrm{mI}$.). "The arerage value of three independent determinations. The experimental ralues deriate Irom the reported values by an average ol $10^{\circ}$.
$\mathrm{CH}_{2} \mathrm{Cl}_{2}$ and $0.50 \mathrm{~mL}$ of $10 \%$ (v/ $)$ tris(2-butoxyethyl) phosphate (TBEP) in $\mathrm{CH}_{2} \mathrm{Cl}_{2}$, and $2.0 \mathrm{~mL}$ of the ligand 4 ( $1.0 \mathrm{mM}$ ) in $\mathrm{CH}_{2} \mathrm{Cl}_{2}$. The NPOE and TBEP were used as membrane plasticizers. The solvent of this mixed solution was allowed to slowly exaporate in a $9.0 \mathrm{~cm}$ diameter petri dish which was covered by a watch glass. After 18-hour evaporation, a few drops of water were swirled on top of the film to help loosen it from the glass. ${ }^{-}$The poly mer film was then carefully peeled off the petri dish. The thickness of the membrane film was $30 \mu \mathrm{m}$. The membrane was placed between $200 \mathrm{~mL}$ of two cy lindrical glass vessels. The area of the membrane was $19.6 \mathrm{~cm}^{2}$. Both source and receiving aqueous phase were stirred with glass stirrers at about 600 rpm by synchronous motors at $25^{\circ} \mathrm{C}$. The initial concentration of $\mathrm{LiNO}_{3}, \mathrm{NaNO}_{3}, \mathrm{KNO}_{3}, \mathrm{RbNO}_{3}, \mathrm{CsNO}_{3}, \mathrm{Mg}\left(\mathrm{NO}_{3}\right)_{2} . \mathrm{Ca}\left(\mathrm{NO}_{3}\right)_{2}$. $\mathrm{Sr}\left(\mathrm{NO}_{5}\right)_{2}$, and $\mathrm{Ba}\left(\mathrm{NO}_{3}\right)_{2}$ was $0.010 \mathrm{M}$, respectively. $5.0 \mathrm{~mL}$ from the receiving phase was periodically taken and the metal cations transported from source phase into receiving phase through PIM were deternined by atomic absorption spectrometer. Three independent experiments were employed in the detemination of each cation transport rate and pemeability constant. The standard deviations were less than $\pm 10 \%$.

\section{Results and Discussion}

The synthetic scheme for + is shown in Scheme 1. Synthetic procedures for the target molecule were followed the method for para-teri-octy lcalix[6]arene derivatives already reported. ${ }^{5}$ To attach the three carboxylic acids on lower rim of the calix[6]arene unit by 1.3.5-alternative type, selective methylation should be carried out in advance. Alkylation of 1 with ethyl 2-bromoacetate in the presence of metal carbonate gave a low yield (less than 10\%). So, we carried out amidoalky lation using $x, x$-diethy 2 -chloroacetamide prior to attaching the three carboxylic acids. then we obtained compound 2 in $80 \%$ yield. Demethylation of 2 using iodotrimethylsilane and sodium perchlorate gave 3 as a white crystal in $66 \%$ yield. Alkylation of 3 using 2-bromoacetic acid and $\mathrm{NaH}$ as a base in THF gave the desired target
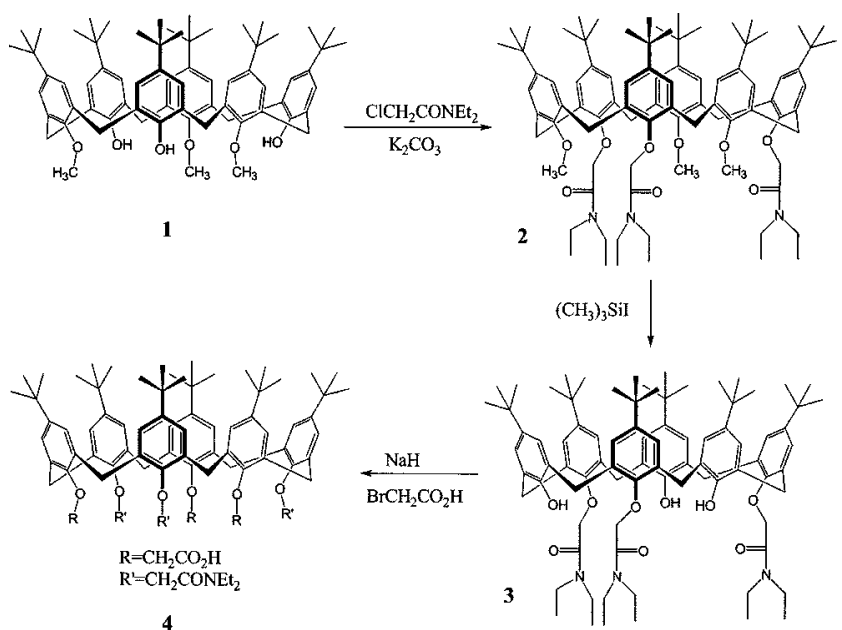

Scheme 1. Synthetic scheme for 4. 
Table 2. Iren1sport rates of alkali metul ions and alkuline²-earth metal ions through a PIM using 4

\begin{tabular}{|c|c|c|c|c|c|c|c|c|c|}
\hline & \multicolumn{9}{|c|}{ Transport rate $\left(10^{-5} \mathrm{~mol}^{-1} \cdot \mathrm{h}^{-1} \mathrm{~m}^{-2}\right)^{a}$} \\
\hline & $\mathrm{Li}$ & $\mathrm{Na}{ }^{\circ}$ & $\mathrm{K}^{*}$ & $\mathrm{Rb}^{\circ}$ & $\mathrm{Cs}^{\circ}$ & $\mathrm{Mg}^{21}$ & $\mathrm{Ca}^{2}$ & $\mathrm{Sr}^{2}$ & $\mathrm{Ba}^{2}$ \\
\hline 4 & 0 & 6.10 & 8.45 & 0 & 1.64 & 3.22 & 6.73 & 10.57 & 124.88 \\
\hline
\end{tabular}

"lranspon condition: source phase (aqueous solution of metal nitrate $10 \mathrm{mM}$ ). membrane phase (CTA membrane). |canter| - $1.0 \mathrm{mM}$ : receiving phase; deionized waler.

molecule 4 as a white solid in $82 \%$ y ield.

To measure the binding ability of the 4 toward alkali and alkaline-earth metal ions, firstly we used a bulk liquid membrane (BLM) system. The results of the measurement of single ion transport rate are described in Table l. Among alkali metal ions. $\mathrm{K}^{\prime}$ ion was found to move the most rapidly from source into receiving phase through bulk organic medium by a rate of $14.28 \times 10^{-8} \mathrm{~mol} \mathrm{~s} \mathrm{~m}^{-1}$. For alkalineearth metal ions, the transport rate of $\mathrm{Ba}^{2}{ }^{21}$ ion was the largest by $21.33 \times 10^{-8} \mathrm{~mol} \mathrm{~s}^{-1} \mathrm{ml}^{--}$. So. it is presumed that $\mathrm{Ba}^{2}$ ion is selectively bound to the calix[6]arene 4 , then demetalation rate from organic medium into the receiving phase is also fast although the rate-determining step between two process (complexation and decomplexation) could not be determined.

To study the binding ability of the 4 considering transport rate from source phase into receiving phase by an organic medium. we used a polymeric inclusion membrane (PIM) which is modeled after the diketone-containing membranes developed by Sugiura. "They are fomed by the poly merization of cellulose triacetate (CTA) to give a thin film. The PIM is then placed between an aqueous source and a receiving phase. While PIM can effectively separate two aqueous plases. they are independent of the organic solvents in maintaining phase separation and in allowing continuous transport. Transport rates of the alkali and alkaline-earth metal ions through PIM when ligand 4 were used are listed in Table 2. Like in the case of BLM. $\mathrm{Ba}^{2}$ ion was found to give a selective transport through the PIM. Selectivity of $\mathrm{Ba}^{2} / \mathrm{Mg}^{-1}$ is more than to which is the largest value ever known so far. In a control experiment, no transport rate was detected in the absence of the ligands during more than 60 hour contimuous nun.

Permeability coefficient $\left(P, \mathrm{~m} \cdot \mathrm{s}^{-1}\right)$ was detemined by plotting the logarithun of $\mathrm{Cs} / \mathrm{Co}$ w time according to Eq. (1)

$$
\ln (\mathrm{Cs} / \mathrm{Co})=-(\mathrm{PS} / \mathrm{V}) 1
$$

where $\mathrm{Co}_{\mathrm{O}}$ is the initial concentration of the cation in the source phase. Cs denotes the metal ion concentration in the source phase as a function of time. $\mathrm{V}$ and $\mathrm{S}$ are for volume of source phase and for membrane area, respectively. ${ }^{\&}$ To

Table 3. Iogarithm of petmeability coefficients of alkali metal ions and alkaline-carth melal ions using 4

\begin{tabular}{|c|c|c|c|c|c|c|c|c|c|}
\hline \multirow{2}{*}{ Mctal } & \multicolumn{9}{|c|}{$\log P\left(m-s^{-1}\right)^{a}$} \\
\hline & $1 i^{-}$ & $\mathrm{Na}^{-}$ & $\mathrm{K}^{-}$ & $\mathrm{Rb}^{+}$ & $\mathrm{Cs}^{+}$ & $\mathrm{Mg}^{2-}$ & $\mathrm{Ca}^{2-}$ & $\mathrm{Sr}^{\mathrm{z}^{-}}$ & $\mathrm{H}^{3} \mathrm{a}^{2+}$ \\
\hline & 0 & -5.10 & -5.00 & 0 & -5.70 & -5.40 & -5.10 & -500 & -4.00 \\
\hline
\end{tabular}

"Transpon condition: source phase (aqueous solution of metal nitrate 10 $m \mathrm{M}$ ): membrane plose (CTA membrane): [canier] - $1.0 \mathrm{mM}$; receiving phase: deionized water. obtain the permeability coefficient of the alkali and alkalineearth metal ions, several different experimental sets were performed. The results are listed in Table 3 and depicted in Figure 1 and Figure 2. The slope for $\ln (\mathrm{Cs} / \mathrm{Co}) /(\mathrm{S} / \mathrm{V})$ w time $(h)$ indicates the perneability coefficient $(P)$. Potassium ion provided the largest permeability coefficient $(-5.0)$ among alkali metal ions. In the case of alkaline-earth metal ions, barium ion gave -4.0 of permeability coefficient that is the largest among alkaline-earth metal ions. The Log $P$ values increased with carrier concentration and reach a maximum

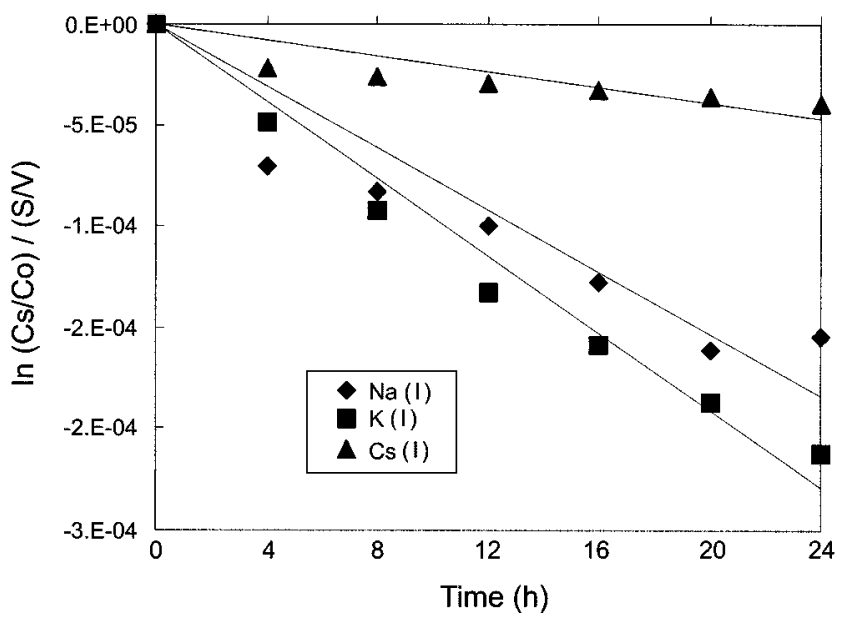

Figure 1. Kinetic plot of the permeability for alkali metal ions as a function of time (h) through a PIM. Source phase: aqueous solution of $10 \mathrm{mM}$ melal nitrate: membrane phase: C'TA membrane: [carrier] $=1.0 \mathrm{mM}$ : roceiting phas: deionized water.

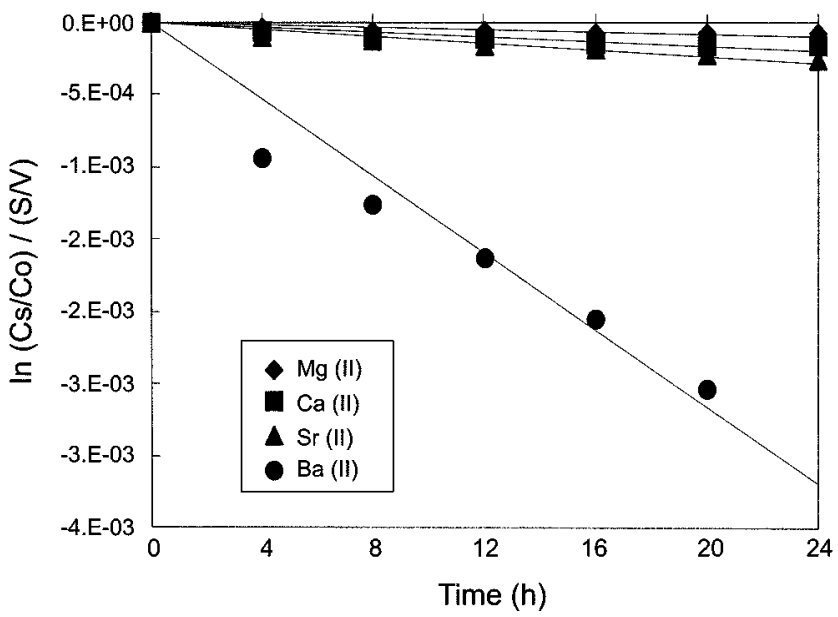

Figure 2. Kinctic plot of the permability for alkaline-sarth metal ions as a lunction of time (h) Urough a PIM. Source phase: aqueous solution of $10 \mathrm{mM}$ metal nitrate; membrane phase: CTA membrame; с сагтier $]=1.0 \mathrm{mM}$; receiving phase: deionized water. 
at $10 \mathrm{mM}$ of 4 . This relationship also complies with the diffusion-based mathematical model for organic ligand across a liquid membrane described by McBride. ${ }^{\text {ij }}$ To examine the long-term stability of the PIMs, sime membrane containing 4 was repeatedly reloaded in successive experiments. Measurement of the transport flux every 4hour gave constant values up to 30 days. After 30 days we observed some rust in the membrane. then observed small decline of permeability. PIM system retained a transparent solution without any loss of the organic materials into aqueous solutions during 30-days of stirring. indicating its excellent durability:

Acknowledgment. This research was fully supported from a Grant from KISTEP (M202060004+-01B050000110). We also gratefully thank KBSI in Daejon for the instrumentation support ( ${ }^{1} \mathrm{H} .{ }^{1.3} \mathrm{C}$ NMR. and Mass spectroscopy).

\section{References}

1. Gunsche. C. D. Calixentes. Royal Society of Chemistry: Cambridge. 1989.

2. Gulsche. C. D. In Sinthesis of Aacrocuctes: Design of Setective Complexing lgemts, I7att, R. M. Cluristensen. J. J., Гds.: Wiley: Now York, 1987; 93

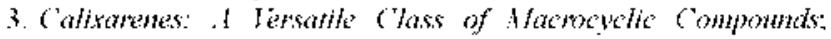
Vicens. J. Böhmer. V.. Eds.: Kluwer: Dordrech1. 1991.
4. (a) Casnati. A.: Pochini. A.: Ungaro. R.: Ugoczoli. F.: AnandNeu. f.: Ftami. S.: Schwing. M.-J.: Egberink. R. J. M.: de Jong. F.: Reinhoudt. D. N. J. Am. Ch'm. Soc. 1995. H7. 2767. (b) Hill. C.: Dozol, J.-F.: Lamare, V: Rouquette, I I.: Fymard. S.: Toutnois. B.: Vicens, J.: Astari, 7.: Bressot. C.: Ungaro, R.: Castnati. A.J. Incl. Phenom 1994, 19, 399. (c) Astari. 7.: Abidi. R.: Arnaud-Neu. F.: Vicens. I. J. Incl. Ihthom. 1992. I3. 163. (d) Astari. $L$.: Weiss. J.: Pappalardo. S.: Vicens. J. The Appl. Chem. 1993. 65. 585. (e) Kim. J. S.: Sull. I. H.: Kim. J. K.: Cho. M. H. J. Chem. Soc., Perkin Trans: / 1998, 2307. (t) Kim. I. S: Ohti, A.: Uehi, R.: Ishizuka, T: Shimotashiro. T.: Macda, S. Falonta 19y9. \$8. 705. (g) Kim. J. S. Shon. O. J: Ko, J. W.: Cho. M. H.: Yu. I. Y.: Vicens. J. J. Org. Chem. 2000. 65. 2386, (li) Kim. J. S.: Panly. J. H.: Yu. I. Y.: Lee. W. K.: Sul. I. H.: Kim. đ. K.: Cho. M. H.: Kim. E. T.: Ra. D. Y, J, Chem. Soc, Perkin Thoms, 2 1999. 837. (i) Kim. J. S.: I.e, W. K.: Suh, I. II.: Kim, I. C.: Yoon, J. Y.: I.ce, I. H. J. Org. (hem. 2000. 65.7215. (j) Kim. J. S.: I.c. W. K.: No, K. I.: Asfari, 7.: Vicens, J. Tetrohedron Lett. 2000. H, 3.345.

5. Ludwig. R.: Kunogi. K.: Dung. N.: lachimori. S. Chem. Commm. 1997. 1985 .

6. Kim. J. S.: Kim. S. K.: Ko. J. W.: Kim. E. T:: Yu. S. H.: Cho. M. II.: Kwon, S. G.: I.ce. F. H. Talonta 2000. 52. 114.3.

7. Sugiura, M. Sep. Sci. Tech 1990. 25, 1189

8. Show A. J.: Peterson, R. T.: I.amb. I. D. J. Membrane Sci. 1996. HI. 291 .

9. Kim. J. S.: Shon. O. J.: Sim. W.: Kim. S. K.: Cho. M. H.: Sul. I. H.: Kim. I. G.: Kim. D. W, J. Chem. Soc. Pertim Troms. / 2001. 31

10. MeBride, D. W. I7att, Ir.. R. M.: I.amb, I. D.: Christensen. J. I. Inclusion (ompounds $\mathrm{HT}$, Acadenic Press: I.ondon, 1984: $\mathrm{pp}$ $571-628$. 